Website: https://ojs.unikom.ac.id/index.php/common

DOI Jurnal: https://doi.org/10.34010/common

DOI Artikel: https://doi.org/10.34010/common.v4i2.4436

\title{
PEMANFAATAN APLIKASI ZOOM CLOUD MEETING SEBAGAI MEDIA E-LEARNING DALAM MENCAPAI PEMAHAMAN MAHASISWA DI TENGAH PANDEMI COVID-19
}

\author{
Radisya Eka Putri H. ${ }^{1}$, Tine Agustin Wulandari ${ }^{2}$ \\ Program Studi Ilmu Komunikasi, Fakultas Ilmu Sosial dan Ilmu Politik, Universitas Komputer \\ Indonesia, Jalan Dipati Ukur 102-116, Bandung, 40132, Indonesia ${ }^{1,2}$ \\ E-Mail: \\ radisyaeph@mahasiswa.unikom.ac.id ${ }^{1}$, tine.wulandari@email.unikom.ac.id ${ }^{2}$
}

\begin{abstract}
The pandemic of Covid-19 caused the Indonesian government to issue regulations about the implementation of e-learning as a substitute for face-to-face learning. Zoom Cloud Meeting application is one of the e-learning media used in order to achieve students understanding in the midst of pandemic. The research was conducted through a qualitative approach with a case study in one of the department which has the largest number of students at Universitas Komputer Indonesia. Through the purposive technique, six research informants were obtained, consisting of quality assurance coordinator, lecturers and students involved in the learning process using Zoom Cloud Meeting application. Results showed that planning contained an overview of learning activities to be held with Zoom Cloud Meeting media as well as preparations made by lecturers and students. Implementation is the use of Zoom Cloud Meeting application as the media of e-learning to deliver learning materials, in the same way as face-to-face learning, consisting of lectures and discussions. Evaluation is related to technical barriers and the development of learning materials that should be adjusted to e-learning method through Zoom Cloud Meeting application. Researchers concluded, the use of Zoom Cloud Meeting application as the media of e-learning in general has successfully achieving students understanding in the midst of pandemic through various features that support the implementation of e-learning, this happens after all parties involved can adapt to the elearning system. For that, it is necessary to conduct further research about the impact of e-learning in the improvement the learning quality of students. This research was conducted as part of e-learning development, although it cannot completely replace face-to-face learning but at least supports the learning process by utilizing technological advances so that students are more active and independent, because the learning process is no longer centered on lecturers.
\end{abstract}

Keywords: e-learning, Zoom Cloud Meeting, media, students understanding, Covid-19 pandemic.

\begin{abstract}
Abstrak
Pandemi Covid-19 menyebabkan Pemerintah RI mengeluarkan peraturan untuk menyelenggarakan e-learning sebagai mengganti pembelajaran tatap muka. Aplikasi Zoom Cloud Meeting merupakan salah satu media e-learning yang digunakan dengan tujuan untuk mencapai pemahaman mahasiswa di tengah pandemi. Penelitian dilakukan melalui pendekatan kualitatif dengan studi kasus pada salah satu program studi yang memiliki jumlah mahasiswa terbanyak di Universitas Komputer Indonesia. Melalui teknik purposive, diperoleh enam informan penelitian, terdiri dari coordinator penjamin mutu, dosen dan mahasiswa yang terlibat dalam perkuliahan menggunakan aplikasi Zoom Cloud Meeting. Hasil penelitian menunjukan bahwa perencaaan memuat gambaran umum kegiatan perkuliahan yang akan diselenggarakan dengan media Zoom Cloud Meeting serta persiapan yang dilakukan oleh dosen dan mahasiswa. Implementasi merupakan penggunaan aplikasi Zoom Cloud Meeting sebagai media e-learning untuk menyampaikan materi perkuliahan, dengan tata cara yang sama dengan perkuliahan tatap muka, terdiri dari ceramah dan diskusi. Evaluasi berkenaan dengan kendala teknis dan pengembangan materi perkuliahan yang seharusnya menyesuaikan dengan metode e-learning melalui aplikasi Zoom Cloud Meeting. Peneliti menyimpulkan, pemanfaatan aplikasi Zoom Cloud Meeting sebagai media e-learning secara umum dapat membantu dalam mencapai pemahaman mahasiswa di tengah pandemi melalui berbagai fitur yang mendukung pelaksanaan e-learning, hal ini terjadi setelah semua pihak yang
\end{abstract}


Jurnal Common | Volume 4 Nomor 2 | Desember 2020

Website: https://ojs.unikom.ac.id/index.php/common

DOI Jurnal: https://doi.org/10.34010/common

DOI Artikel: https://doi.org/10.34010/common.v4i2.4436

terlibat dapat beradaptasi dengan sistem e-learning. Untuk itu, perlu dilakukan penelitian lanjutan mengenai dampak elearning dalam meningkatkan kualitas belajar mahasiswa. Penelitian ini dilakukan sebagai bagian dari pengembangan e-learning, walaupun tidak dapat sepenuhnya menggantikan perkuliahan tatap muka tetapi setidaknya mendukung proses pembelajaran dengan memanfaatkan kemajuan teknologi agar mahasiswa lebih aktif dan mandiri, karena proses pembelajaran tidak berpusat pada dosen.

Kata Kunci: e-learning, Zoom Cloud Meeting, media, pemahaman mahasiswa, pandemi Covid-19. 
Website: https://ojs.unikom.ac.id/index.php/common

DOI Jurnal: https://doi.org/10.34010/common

DOI Artikel: https://doi.org/10.34010/common.v4i2.4436

\section{Pendahuluan}

\subsection{Latar Belakang Masalah}

Nilai dari sesuatu yang memiliki guna adalah dengan memperoleh hasil dari penggunaan sesuatu yang dapat memberikan manfaat. Di tengah situasi yang terbatas karena pandemi Covid-19, masyarakat harus dapat menyesuaikan diri diantaranya dengan memanfaatkan kemajuan teknologi yang ada sebagai penunjang berbagai kegiatan dalam kehidupan sehari-hari. Segala sesuatu yang biasa dilakukan secara tradisional, langsung, dan tatap muka kini beralih menjadi online atau daring. Pemanfaatan teknologi sebagai penunjang kehidupan perlu dilakukan dengan cara yang tepat untuk memperoleh hasil yang maksimal. Situasi pandemi Covid-19 telah memisahkan orang-orang untuk bertatap muka langsung karena perlunya pembatasan sosial untuk mencegah penyebaran virus. Sehingga perserta didik dari tingkatan paling dasar hingga mahasiswa harus belajar dengan sistem pembelajaran menggunakan sumber online dari internet dan jarak jauh (e-learning) melalui teknologi informasi dan komunikasi.

Pemerintah RI melalui Kementerian Pendidikan dan Kebudayaan (Kemendikbud), telah mengeluarkan surat edaran yang melarang sekolah maupun perguruan tinggi untuk melaksanakan pembelajaran tatap muka, diganti dengan sistem e-learning. Diantaranya Surat Edaran Direktur Jenderal Pendidikan Tinggi Republik Indonesia Nomor 1 Tahun 2020. Sehingga berbagai Perguruan Tinggi di Indonesia dengan cepat merespon surat edaran yang terdiri dari 11 poin tersebut, agar keberlangsungan proses pendidikan dapat tetap berjalan dan dilakukan oleh seluruh sivitas akademika.

E-learning adalah pembelajaran yang disusun dengan menggunakan perangkat elektronik atau komputer sehingga mampu mendukng proses pembelajaran (Michael,
2013: 27). Pembelajaran dengan metode $e$ learning menekankan pada keaktifan peserta didik dan dipandu oleh pendidik secara jarak jauh tanpa tatap muka secara langsung, penyampaian materi, interaksi, serta tugas sepenuhnya dilakukan secara daring menggunakan Internet.

E-learning menjadi salah satu solusi penyelenggaraan proses pembelajaran di tengah pandemi, sehingga keterpisahan ruang dan waktu antara pendidik dan peserta didik (dalam penelitian ini adalah dosen dan mahasiswa) diatasi dengan jaringan internet. Tetapi perlu adanya media untuk mengakomodasi kegiatan e-learning agar menjangkau seluruh mahasiswa yang terlibat dan mampu menyampaikan materi perkuliahan dengan efisiensi waktu, biaya, dan kemudahan akses dari para pesertanya. Hal tersebut ditempuh salah satunya melalui video conference. Tetapi ketelitian dan kejelian mahasiswa perlu ditingkatkan ketika menerima dan mengolah informasi atau materi perkuliahan yang disajikan secara daring.

Dalam prosesnya, banyak mahasiswa yang mengeluhkan berbagai permasalahan yang dihadapi selama kuliah daring dari rumah, terutama hambatan teknis, mulai dari keterbatasan jaringan internet atau tidak adanya fasilitas jaringan internet, hingga beban tugas yang diberikan terlalu banyak. Walaupun begitu, e-learning juga memiliki banyak kelebihan, diantaranya keluwesan waktu dan lokasi kuliah, perkuliahan dapat dilaksanakan di kamar, ruang tamu, dan waktunya pun dapat dilaksanakan di luar jadwal yang telah ditentukan sesuai dengan kesepakatan bersama antara dosen dan mahasiswa.

Terdapat berbagai pilihan perangkat lunak maupun aplikasi yang dapat dimanfaatkan sebagai media e-learning, terutama untuk menyelenggarakan perkuliahan melalui video conference. Aplikasi Zoom Cloud Meeting termasuk aplikasi video conference yang namanya semakin populer 
Website: https://ojs.unikom.ac.id/index.php/common

DOI Jurnal: https://doi.org/10.34010/common

DOI Artikel: https://doi.org/10.34010/common.v4i2.4436

selama pandemi karena banyak dipilih sebagai fasilitas video conference dalam berbagai kegiatan, termasuk di perguruan tinggi. Dibandingkan fasilitas video conference lainnya, Zoom Cloud Meeting banyak dipilih karena kemudahan dalam penggunaannya dan disertai dengan fitur yang lengkap yang menunjang proses $e$-learning.

Pemahaman mahasiswa menjadi salah satu hasil yang menunjukkan keberhasilan $e$ learning. Hal tersebut tentu saja tidak hanya bergantung kepada Zoom Cloud Meeting tetapi juga kemampuan mahasiswa untuk memahami materi dan informasi yang diterimanya selama proses e-learning berlangsung.

Universitas Komputer Indonesia (Unikom), seperti halnya perguruan tinggi lainnya di seluruh Indonesia, menerapkan $e$ learning selama pandemic berlangsung. Pada awal penerapan sistem e-learning, banyak dosen yang memilih Zoom Cloud Meeting sebagai media e-learning untuk menggantikan perkuliahan tatap muka. Walaupun sebetulnya Unikom memiliki fasilitas video conference tersendiri. Tetapi karena kebijakan e-learning yang dapat dikatakan mendesak, fasilitas tersebut belum dapat dimanfaatkan secara optimal oleh sivitas akademika Unikom.

Terdapat beberapa penelitian terdahulu yang berkaitan dan relevan dengan penelitian yang dilakukan, yaitu mengenai pemanfaatan teknologi sebagai media pembelajaran berbasis e-learning antara lain:

Pertama, Pengaruh Pemanfaatan Simari Sebagai Implementasi Pembelajaran Berbasis E-Learning Terhadap Hasil Belajar Mahasiswa Program studi Pendidikan Ekonomi. Penelitian yang dilakukan oleh Meliyani Meliyani, Supriyanto, dan Muhammad Rahmattullah pada tahun 2019 ini, diterbitkan di jurnal ilmiah Universitas Lambung Mangkurat. Menggunakan metode kuantitatif dengan sampel sebanyak 73 mahasiswa, pengumpulan data dilakukan melalui angket. Sehingga diperoleh hasil penelitian sebagai berikut:

a. Pemanfaatan SIMARI dalam e-learning berada pada kategori cukup baik;

b. Hasil belajar siswa berada pada kategori cukup tinggi;

c. Terdapat pengaruh yang signifikan pemanfaatan SIMARI sebagai implementasi pembelajaran berbasis $e$ learning terhadap hasil belajar siswa yang ditunjukkan dengan $\mathrm{F}$ hitung sebesar 4,554 dengan signifikansi 0,036.

Perbedaan dengan penelitian yang dilakukan terdapat pada metode yang digunakan karena penelitian yang dilakukan menggunakan pendekatan kualitatif dengan metode studi kasus, sehingga data primer diperoleh melalui wawancara bukan angket. Perbedaan metode penelitian tentu saja berakibat pada berbagai aspek penelitian serta hasil penelitian yang sangat berbeda.

Kedua, Penggunaan YouTube Channel oleh Trainer DJ Arie School Bandung (Studi Deskriptif Mengenai Penggunaan Youtube Channel oleh Trainer DJ Arie School Bandung Sebagai Media Pelatihan Public Speaking Di Kalangan Penonton YouTube Channel-Nya). Penelitian yang dilakukan oleh Aldi Salman Renaldi sebagai skripsi pada program studi Ilmu Komunikasi di Unikom ini menggunakan pendekatan kualitatif dengan studi deskriptif. Hasil penelitian diperoleh bahwa:

a. Pelatihan public speaking secara daring ditinjau dari perencanaan, implementasi, dan evaluasi pada platform YouTube Channel yang digunakan sebagai media e-learning oleh DJ Arie School kepada penonton channel-nya.

b. DJ Arie School membuat konten YouTube Channel yang memberikan simulasi agar dapat langsung diterapkan oleh penonton channel-nya serta sebagai aplikasi dari pelatihan public speaking. Perbedaan dengan penelitian yang dilakukan terdapat pada studi yang diigunakan, 
Website: https://ojs.unikom.ac.id/index.php/common

DOI Jurnal: https://doi.org/10.34010/common

DOI Artikel: https://doi.org/10.34010/common.v4i2.4436

karena penelitian ini menggunakan studi kasus. Selain itu, terdapat perbedaan pada objek yang diteliti, serta platform yang diteliti bukan YouTube Channel.

Berdasarkan uraian tersebut, penelitian terdahulu sangat berguna sebagai bahan acuan penelitian namun tetap terdapat perbedaan yang menjadikan penelitian ini masih menarik untuk dilakukan karena terdapat perbedaan yang sangat jelas. Adapun tujuan dari penelitian ini juga sangat aktual dengan kondisi saat ini, yaitu mengkaji pemanfaatan media $e$ learning melalui video conference yang digunakan selama masa pandemi untuk menggantikan perkuliahan tatap muka dan mencapai pemahaman mahasiswa.

\subsection{Rumusan Masalah}

Sesuai dengan latar belakang penelitian yang telah dijelaskan, rumusan masalah makro dalam penelitian ini adalah "bagaimana pemanfaatan aplikasi Zoom Cloud Meeting sebagai media e-learning dalam mencapai pemahaman mahasiswa di tengah pandemi Covid-19?"

Untuk menjawab permasalahan tersebut, diperlukan batasan penelitian yang disebut juga rumusan masalah mikro sebagai berikut:

1. Bagaimana perencanaan dalam pemanfaatan aplikasi Zoom Cloud Meeting sebagai media e-learning dalam mencapai pemahaman mahasiswa di tengah pandemi Covid-19?

2. Bagaimana implementasi aplikasi Zoom Cloud Meeting sebagai media e-learning dalam mencapai pemahaman mahasiswa di tengah pandemi Covid-19?

3. Bagaimana evaluasi aplikasi Zoom Cloud Meeting sebagai media e-learning dalam mencapai pemahaman mahasiswa di tengah pandemi Covid-19?

\subsection{Maksud dan Tujuan Penelitian}

Penelitian bermaksud untuk mengetahui dan menjelaskan secara mendalam tentang pemanfaatan aplikasi Zoom Cloud Meeting sebagai media e-learning dalam mencapai pemahaman mahasiswa di tengah pandemi Covid-19. Adapun secara spesifik, tujuan dari penelitian ini adalah:

1. Untuk mengetahui perencanaan dalam pemanfaatan aplikasi Zoom Cloud Meeting sebagai media e-learning dalam mencapai pemahaman mahasiswa di tengah pandemi Covid-19.

2. Untuk mengetahui implementasi aplikasi Zoom Cloud Meeting sebagai media $e$ learning dalam mencapai pemahaman mahasiswa di tengah pandemi Covid-19.

3. Untuk mengetahui evaluasi aplikasi Zoom Cloud Meeting sebagai media $e$ learning dalam mencapai pemahaman mahasiswa di tengah pandemi Covid-19.

\subsection{Kegunaan Penelitian}

Hasil dari penelitian ini dapat dijadikan rujukan, masukan, dan evaluasi bagi institusi pendidikan, terutama perguruan tinggi dalam melaksanakan e-learning khususnya melalui video conference dengan menggunakan aplikasi Zoom Cloud Meeting, serta bagi pihak-pihak yang terlibat dalam proses $e$ learning, diantaranya: pendidik (guru maupun dosen), peserta didik (siswa maupun mahasiswa), bahkan orang tua dan masyarakat secara umum. Agar dapat memahami dan mengembangkan sistem e-learning agar dapat terlaksana dengan baik untuk mencapai pemahaman peserta didik.

Penelitian ini juga memberikan pandangan positif bagi masyarakat mengenai penggunaan teknologi yang bermanfaat dalam sistem pembelajaran jarak jauh. Selain itu, penelitian ini berkontribusi dalam mengembangkan ilmu komunikasi, tertuma komunikasi dengan menggunakan media baru (internet), karena pada dasarnya pemahaman 
Website: https://ojs.unikom.ac.id/index.php/common

DOI Jurnal: https://doi.org/10.34010/common

DOI Artikel: https://doi.org/10.34010/common.v4i2.4436

mahasiswa akan tercapai jika proses komunikasi yang berlangsung dalam sistem $e$ learning berjalan secara efektif.

\section{Kajian Pustaka dan Kerangka Pemikiran}

\subsection{E-Learning}

\section{Electronic learning atau e-learning} adalah proses pembelajaran berbasis elektronik. Salah satu media yang digunakan adalah jaringan komputer. E-learning merupakan adaptasi dari sistem konvensional ke dalam sebuah sistem digital melalui internet. Manfaat e-learning dikemukakan oleh Pranoto, dkk (2009):

1. Penggunaan e-learning untuk menunjang pelaksanaan proses belajar dapat meningkatkan daya serap mahasiswa atas materi yang diajarkan;

2. Meningkatkan partisipasi aktif dari mahasiswa;

3. Meningkatkan kemampuan belajar mandiri mahasiswa;

4. Meningkatkan kualitas materi pendidik dan pelatihan;

5. Meningkatkan kemampuan dalam menampilkan informasi dengan perangkat teknologi informasi, dimana dengan perangkat biasa sulit dilakukan.

Kelebihan pembelajaran menggunakan e-learning yaitu, tersedianya fasilitas emoderating dimana pendidik dan peserta didik dapat berkomunikasi secara mudah melalui fasilitas internet secara reguler atau kapan saja kegiatan berkomunikasi itu dilakukan tanpa dibatasi oleh jarak, tempat, dan waktu. Pembelajaran dilakukan terstruktur dan terjadwal melalui internet. Peserta didik pun seprti mahasiswa dapat belajar (me-review) bahan ajar setiap saat dan dimana saja apabila diperlukan mengingat bahan ajar tersimpan di komputer. Bila mahasiswa memerlukan tambahan informasi yang berkaitan dengan bahan yang dipelajarinya, mahasiswa dapat melakukan akses internet. Sehingga berubahnya peran mahasiswa dari pasif menjadi aktif. Sedangkan kekurangan pembelajaran menggunakan metode $e$ learning pada Pendidikan Tinggi tidak terlepaskan dari kurangnya interaksi langsung antara dosen dan mahasiswa. Adanya kecenderungan mengabaikan aspek akademik dan aspek sosial. Proses pembelajaran cenderung ke arah pelatihan daripada pendidikan dikarenakan pembelajarannya dilakukan secara daring. Pendidik juga dituntut juga untuk menguasai ICT (Information Communication Technology) serta mempunyai akses internet agar dapar melaksanakan pembelajaran.

\subsection{Pemahaman}

Di dalam proses pembelajaran, setiap individu yang terlibat, dalam hal ini mahasiswa, memiliki kemampuan yang berbeda-beda dalam memahami apa yang dipelajari. Pemahaman merupakan salah satu patokan dari hasil yang dicapai setelah proses pembelajaran.

Suharsimi (2009) menyatakan bahwa pemahaman (comprehension) adalah bagaimana seseorang mempertahankan, membedakan, menduga (estimates), menerangkan, memperluas, menyimpulkan, mengeneralisasikan, memberikan contoh, menuliskan kembali, dan memperkirakan. Dengan pemahaman, mahasiswa dapat diminta untuk membuktikan dan memahami hubungan sederhana antara fakta-fakta dan konsep.

Ada beberapa faktor yang dapat mempengaruhi pemahaman, yaitu:

1. Usia sangat mempengaruhi daya tangkap dan pola pikir seseorang, semakin bertambah usianya maka daya dan pola pikir serta daya tangkapnya semakin meningkat.

2. Jenis kelamin juga mempengaruhi pemahaman. Pusat memori otak 
Website: https://ojs.unikom.ac.id/index.php/common

DOI Jurnal: https://doi.org/10.34010/common

DOI Artikel: https://doi.org/10.34010/common.v4i2.4436

perempuan cenderung lebih besar dibandingkan laki-laki, sehingga perempuan mempunyai pemahaman yang cepat dibandingkan laki-laki.

3. Pendidikan sangat mempengaruhi proses belajar, semakin tinggi pendidikan seseorang maka semakin mudah orang tersebut menerima informasi. Pendidikan yang tinggi akan mudah memahami sesuatu baik dari orang lain maupun media yang ada.

\subsection{Kerangka Pemikiran}

Sa'ud (2010) dalam buku Inovasi Pendidikan menyatakan bahwa pada proses pembelajaran dengan sistem e-learning mencakup tiga aspek, yaitu: perencanaan, implementasi, dan evaluasi. Adapun penjabaran ketiga aspek tersebut ke dalam permasalahan penelitian, antara lain:

1. Perencanaan pada dasarnya memuat rencana (skenario), perkiraan dan gambaran umum dari kegiatan pembelajaran. Dalam penelitian ini, perencanaan yang disusun dalam pelaksanaan e-learning khususnya terkait dengan menggunakan Zoom Cloud Meeting sebagai media, untuk mencapai pemahaman mahasiswa di tengah pandemi.

2. Implementasi merupakan penerapan dari hal-hal yang sudah direncanakan. Yaitu bagaimana pelaksanaan e-learning dengan menggunakan aplikasi Zoom Cloud Meeting sebagai media video conference.

3. Evaluasi digunakan untuk mengetahui pencapaian dari tujuan pembelajaran dan tindakan apa yang harus dilakukan apabila tujuan tersebut belum tercapai. Bagaimana evaluasi dilakukan, siapa saja yang terlibat, serta bagaimana tindak lanjut dalam evaluasi tersebut.

\section{Objek dan Metode Penelitian}

Pada masa pandemi Covid-19, setiap institusi pendidikan dihimbau untuk tetap melaksanakan kegiatan pembelajaran, hanya saja sistemnya diubah menjadi pembelajaran dengan sistem e-learning. Objek penelitian yang dipilih adalah salah satu perguruan tinggi yang memiliki visi dan misi berbasis teknologi dalam menyelenggarakan sistem pembelajaran modern dengan memanfaatkan teknologi informasi dan komunikasi melalui optimalisasi sumber daya yang ada berdasarkan budaya organisasi PIQIE (Professionalism, Integrity, Quality, Information Technology, and Excellenc).

Universitas Komputer Indonesia (Unikom) yang didirikan pada tahun 2000 di kota Bandung dan memiliki citra sebagai kampus bertonologi tinggi dipilih sebagai objek penelitian, karena menarik untuk mengetahui bagaimana pelaksanaan e-learning di tengah pandemi pada perguruan tinggi swasta tersebut. Hingga penelitian dilakukan, terdapat 3 program studi magister (S2), 18 program studi sarjana (S1), dan 4 program studi diploma (D3).

Program Studi Ilmu Komunikasi merupakan salah satu program studi jenjang S1 yang memiliki jumlah mahasiswa paling banyak di Unikom. Berdasarkan data dari Biro Administrasi Umum Unikom, Program Studi Ilmu Komunikasi menempati tempat ketiga di Unikom dengan 1.012 mahasiswa aktif pada Semester Genap Tahun Akademik 2019-2020. Sehingga peneliti menetapkan untuk memilih informan dari Program Studi Ilmu Komunikasi. Karena tentu saja, terdapat tantangan yang lebih besar dalam penerapan $e$ learning di program studi yang memiliki banyak mahasiswa.

Informan dipilih dengan menggunakan teknik purposive, yang mewakili struktural program studi, yaitu koordinator penjaminan mutu (quality assurance), dosen dan 
Website: https://ojs.unikom.ac.id/index.php/common

DOI Jurnal: https://doi.org/10.34010/common

DOI Artikel: https://doi.org/10.34010/common.v4i2.4436

mahasiswa yang berasal dari tingkat yang berbeda. Adapun aplikasi Zoom Cloud Meeting dipilih sebagai media e-learning yang diteliti karena aplikasi video conference ini paling banyak digunakan di Program Studi Ilmu Komunikasi, padahal Unikom menyediakan fasilitas BigBlueButtonBN untuk menyelenggarakan video conference.

Penelitian dilakukan menggunakan pendekatan kualitatif dengan metode studi kasus sebagai desain penelitiannya. Moleong (2014) menyatakan, "Penelitian kualitatif adalah penelitian yang bermaksud untuk memahami fenomena tentang apa yang dialami oleh objek penelitian misalnya perilaku, persepsi, motivasi, tindakan, dll, secara holistik, dengan cara deskripsi dalam bentuk kata-kata dan bahasa, pada suatu konteks khusus yang alamiah dan dengan memanfaatkan berbagai metode alamiah".

Hasil penelitian studi kasus bukan untuk melakukan generalisasi fenomena atau peristiwa yang diteliti, tetapi melakukan penelitian bersifat mendalam terhadap fenomena atau kasus sosial yang menjadi objek penelitian. Informan yang telah dipilih secara keseluruhan dapat dilihat pada Tabel 1.

Tabel 1. Informan Penelitian

\begin{tabular}{|c|c|c|}
\hline No. & Nama & Status \\
\hline 1 & $\begin{array}{c}\text { Melly Maulin } \\
\text { Purwaningwulan }\end{array}$ & $\begin{array}{c}\text { Koordinator Quality } \\
\text { Assurance (Penjaminan Mutu) }\end{array}$ \\
\hline 2 & Inggar Prayoga & Dosen Tetap \\
\hline 3 & Kiki Zakiyah & Dosen Tidak Tetap \\
\hline 4 & $\begin{array}{c}\text { Nazla Siti } \\
\text { Febrianti }\end{array}$ & Mahasiswa Tingkat III \\
\hline 5 & Ervinna Engwin & Mahasiswa Tingkat II \\
\hline 6 & $\begin{array}{c}\text { Gussarayuda } \\
\text { Sodiq }\end{array}$ & Mahasiswa Tingkat I \\
\hline
\end{tabular}

\section{Hasil dan Pembahasan}

Unikom sudah memanfaatkan TIK pada semua aktivitas pembelajaran, jauh sebelum memasuki situasi pandemi, terutama internet.
Media terbaru yang digunakan Unikom untuk menunjang proses pembelajaran adalah LMS (Learning Management System). Bukan hanya untuk berbagi materi perkuliahan, tugas, kuis, ujian, hingga video conference juga dapat dilaksanakan melalui LMS. Tetapi, pandemi melanda dan kebijakan pembelajaran jarak jauh diterapkan sebelum sivitas akademika menguasai LMS secara menyeluruh. Penelitian ini dilakukan pada masa awal pandemi, yaitu pada pembelajaran Semester Genap Tahun Akademik 2019-2020. Dimana setiap pihak yang terlibat dalam proses pembelajaran masih berusaha untuk beradaptasi dengan sistem $e$ learning tanpa ada pembelajaran tatap muka secara langsung.

Menurut Sa'ud (2010) dalam buku Inovasi Pendidikan, proses e-learning mencakup tiga aspek: pertama, diawali dari sebuah perencanaan, membuat sebuah rencana (skenario) atau gambaran umum tentang kegiatan pembelajaran dengan menggunakan jaringan komputer, baik intranet maupun internet. kedua, implementasi atau biasanya disebut dengan pengaplikasian dari perencanaan yang telah dibuat. ketiga, evaluasi berfungsi untu mengetahui sejauh mana tujuan tersebut belum tercapai dan tindakan yang harus dilakukan jika tujuannya belum tercapai (Saud, 2010: 206-207).

Selanjutnya peneliti akan menjabarkan hasil penelitian, terkait ketiga aspek tersebut dengan fokus pada pemanfaatan aplikasi Zoom Cloud Meeting sebagai media e-learning pada perguruan tinggi untuk mengganti perkuliahan tatap muka.

\section{Perencanaan dari Pemanfaatan Aplikasi Zoom Cloud Meeting sebagai Media E-Learning Dalam Mencapai Pemahaman Mahasiswa Di Tengah Pandemi Covid-19}


Website: https://ojs.unikom.ac.id/index.php/common

DOI Jurnal: https://doi.org/10.34010/common

DOI Artikel: https://doi.org/10.34010/common.v4i2.4436

\begin{abstract}
Metode yang digunakan dalam proses pembelajaran khususnya dalam mempersiapkan sebuah materi, dimulai dari penyusunan materi yang akan disampaikan, pemanfaatan media yang digunakan dalam penyampaian informasi tersebut digunakan oleh Perguruan Tinggi untuk menyampaikan informasi ataupun metode pembelajaran dan pendekatan terhadap individu-individu selama proses pembelajaran.

Perencanaan penggunaan aplikasi Zoom Cloud Meeting di Perguruan Tinggi merupakan sebuah alternatif sebagai media $e$ learning yang ditujukan untuk mahasiswa, salah satu kunci keberhasilannya yaitu berdasarkan perencanaan sebelumnya dan dapat dipahami mahasiswa pada pembelajarannya menggunakan aplikasi Zoom Cloud Meeting. Alasan penggunaan aplikasi Zoom Cloud Meeting sebagai media video conference yang populer karena dapat menampung 100 orang dalam satu ruang konferensi dan diberikan secara gratis selama 40 menit dan juga beberapa fitur agar kegiatan belajar mengajar tetap berlangsung selama masa pandemi.
\end{abstract}

Diungkapkan oleh Koordinator Penjaminan Mutu (QA) Program Studi Ilmu Komunikasi Unikom, penggunaan aplikasi Zoom Cloud Meeting sebagai media $e$ learning karena Zoom Cloud Meeting termasuk media yang cukup mudah digunakan dengan fasilitas yang memadai untuk melakukan e-learning (Purwaningwulan, Wawancara Penelitian, September 2020).

Informan lain yang merupakan dosen tetap Program Studi Ilmu Komunikasi juga menjelaskan, "Alasan menggunakan aplikasi Zoom Cloud Meeting yaitu, alasan utama karena Aplikasi Zoom Cloud Meeting paling popular, dan yang kedua karena kami (Para Dosen) ditawarkan salah satu alternatifnya ya menggunakan aplikasi Zoom Cloud Meeting ini, sebelumnya pernah coba pakai aplikasi lain hanya ada beberapa masalah di koneksi tapi untuk keamanan Zoom Cloud Meeting paling bagus" (Prayoga, Wawancara Penelitian, 10 September 2020).

Keamanan privasi pada aplikasi Zoom Cloud Meeting sempat ramai diperbincangkan ketika pihak berwenang di Taiwan melarang para pegawai negeri sipil dan institusi publik menggunakannya karena dianggap 'tidak aman' dan alasan keamanan. Pihak Zoom Cloud Meeting telah melakukan perbaikan terhadap polemik tersebut salah satunya dengan selama percakapan yang telah terjadi atau sedang berlangsung, admin dapat melihat sistem operasi, alamat IP, data lokasi dan informasi perangkat masing-masing peserta, sehingga tidak menjadi permasalahan lagi. (https://www.bbc.com/indonesia/majalah-52215642, diakses pada 23 September pukul 20:14).

Berbagai fitur yang terdapat pada Aplikasi Zoom Cloud Meeting seperti:

a. Kualitas gambar dan suara didukung oleh kualitas High Definition atau HD

b. Rekaman (Record) ketika video conference berlangsung

c. Rise hand (angkat tangan) yang juga sangat bermanfaat karena mahasiswa dapat menekan fitur tersebut ketika ingin mengajukan pertanyaan

d. Schedule and join a meeting, fitur ini mengizinkan dosen selaku host dalam aplikasi Zoom Cloud Meeting untuk menjadwalkan perkuliahan yang akan berlangsung

e. Virtual background pada aplikasi Zoom Cloud Meeting memfasilitasi penggunanya untuk mengubah background agar nyaman dilihat di sitiuasi formal seperti perkuliahan.

Informan lain pun menjelaskan bahwa menggunakan aplikasi Zoom Cloud Meeting untuk melaksanakan e-learning, pertama, aplikasi Zoom memiliki kenyamanan untuk melihat tampilan kamera video dengan ukuran yang pas tidak terlalu kecil, sehingga dapat melihat wajah diri sendiri dengan jelas. Selain 
Website: https://ojs.unikom.ac.id/index.php/common

DOI Jurnal: https://doi.org/10.34010/common

DOI Artikel: https://doi.org/10.34010/common.v4i2.4436

itu kemudahan dalam menggunakannya menjadi prioritas utama demi kelancaran dalam berlangsungnya proses e-learning (Zakiyah, Wawancara Penelitian, 10 September 2020).

Para informan yang merupakan pendidik atau dosen telah menjelaskan berbagai alasan untuk menggunakan Aplikasi Zoom Cloud Meeting sebagai media e-learning karena pada awal perkuliahan tatap muka diganti dengan perkuliahan secara daring, media yang digunakan pertama kali untuk menggantikan perkuliahan tatap muka tersebut adalah Aplikasi Zoom Cloud Meeting, sehingga informan hingga saat ini tetap menggunakan aplikasi Zoom Cloud Meeting dan sudah menjadi terbiasa untuk menggunakannya. Hal tersebut membuat para pendidik (dalam hal ini adalah dosen) tidak kewalahan lagi dalam melakukan proses e-learning menggunakan aplikasi video conference secara konsisten untuk kelancaran dan mempersingkat waktu dalam hal persiapan. Adapun persiapan lain yang perlu diperhatikan, yaitu cara penyesuaian pembelajaran dari tatap muka menjadi secara daring, untuk mencapai tujuan pada pemahaman mahasiswa.

Persiapan, yang dilakukan oleh dosen dan mahasiswa pada saat menggunakan Aplikasi Zoom Cloud Meeting untuk proses perkuliahan yang layaknya seperti perkuliahan secara tatap muka langsung, maka perlu adanya persiapan yang matang. Menggunakan aplikasi Zoom sebagai alternatif untuk memudahkan semua pelaku di bidang pendidikan seperti dosen dan mahasiswa untuk mencapai tujuan bersama. Penyesuain yang harus dilakukan seperti beradaptasi dengan teknologinya terutama pada penggunaan berbagai fitur yang terdapat dalam aplikasinya.

Sangat penting program pelatihan bagi tenaga pendidik dalam hal ini ialah dosen yang membantu untuk mengembangkan keterampilannya. Mengingat masih terdapat dosen yang memiliki kurangnya kemampuan dalam menggunakan teknologi maka persiapan dalam hal pelatihan perlu dilakukan. Untuk menunjang kemampuan dosen dalam mengguanakn aplikasi Zoom Cloud Meeting sebagai media e-learning, Program Studi Ilmu Komunikasi Unikom melakukan persiapan dengan mengadakan pelatihan bagi dosen, seperti yang disampaikan oleh informan, "Unikom sebelum melakukan proses elearning mengadakan pelatihan untuk seluruh dosennya, khususnya untuk penggunaan Unikom LMS (Learning Management System)" (Purwaningwulan, Wawancara Penelitian, September 2020).

Persiapan lain yang dilakukan oleh dosen membuat materi yang akan disampaikan dengan media presentasi seperti slide presentasi, rekaman video, gambar, dll. Materi yang disajikan perlu disederhanakan penyampaiannya dikarenakan jangkauan mahasiswa yang jauh sulit untuk dideteksi pemahamannya terhadap materi yang disampaikan selama proses e-learning berlangsung. Maka sesudah melaksanakan $e$ learning pun perlu dipersiapkan, seperti memberikan tugas atau kuis disiapkan sedemikian rupa untuk mengetahui pemahaman mahasiswa setelah pelaksanakan e-learning.

Mahasiswa pun tidak luput melakukan persiapan dalam melaksanakan e-learning, seperti menyiapkan tempat yang tepat dan nyaman agar dapat menerima materi dengan baik dan maksimal, membaca bahan materi yang akan berikan oleh dosen sebelum melaksanakan perkuliahan, persiapan jaringan internet serta persiapan gadget yang mendukung untuk digunakan.

Untuk mencapai efektifitas dalam pembelajran e-learning baik dosen maupun mahasiswa dituntut untuk dapat menyesuaikan situasi pemebelajaran secara daring seperti ini. Karena hal ini belum terbiasa dilakukan, sehingga akan timbul beberapa hambatan untuk mencapai proses e-learning yang efektif. 
Jurnal Common | Volume 4 Nomor 2 | Desember 2020

Website: https://ojs.unikom.ac.id/index.php/common

DOI Jurnal: https://doi.org/10.34010/common

DOI Artikel: https://doi.org/10.34010/common.v4i2.4436

Penyesuaian yang dilakukan oleh dosen lebih kearah pada adaptasi dalam menggunakan teknologinya itu sendiri, "Ada beberapa penyesuaian atau proses yang harus dipersiapkan, seperti share link dan password Zoom Cloud Meeting. Perkuliahan secara tatap muka kita tidak perlu membuat link dan sebagainya. Selanjutnya adaptasi pada aplikasinya seperti mengatur view atau ampilannya kita melihat background dan kondisi mahasiswa yang berbeda-beda" (Prayoga, Wawancara Penelitian, 10 September 2020). Walaupun pembelajaran dilakukan secara daring, etika selama proses pembelajaran masih perlu diterapkan selama $e$ learning berlangsung. Kegiatan perkuliahan tetaplah ada pada situasi formal, sehingga pemilihan tempat dan background, pakaian yang digunakan perlu diperhatikan serta kondisi lingkungan tempat untuk melakukan $e$ learning dengan kondisi yang kondusif.

Keterbatasan waktu yang terdapat pada aplikasi Zoom yang tidak berbayar mengharuskan pendidik (dosen) perlu membagi sesi agar dapat mengefektifkan penggunaan waktu yang tersedia, seperti yang dilakukan oleh salah satu dosen, "Untuk persiapan yang pertama, saya menyiapkan materi dulu yang akan dipersentasikan. Kemudian saya merencanakan waktu karena di aplikasi Zoom Cloud Meeting ini terbatas jadi saya nanti membagi waktu seefektif mungkin. Misalnya 15-20 menit pertama saya menjelaskan materi lalu saya merencanakan beberapa menit berikutnya untuk sesi diskusi dan baru bagian penutup. Jadi saya harus membagi waktu agar dapat efektif perkuliahannya. Kemudian yang tidak kalah penting karna ini daring, saya harus mempersiapkan koneksi yang bagus. Contoh seperti di kampus kita menggunakan wi-fi, jadi saya akan cek terlebih dahulu apakah jaringannya sedang stabil apa tidak agar tidak mengganggu waktu perkuliahan" (Prayoga, Wawancara Penelitian, 09 September 2020).
Dosen perlu mempersiapkan penyampaian materi yang berbeda dengan sebelumnya ketika tatap muka secara langsung. Walaupun karakter mahasiswa tidak sama, tetapi dosen harus dapat menjangkau seluruh mahasiswa agar tidak ada yang tertinggal secara materi. Seperti yang dilakukan oleh Zakiyah selaku dosen di Program studi Ilmu komunikasi Unikom mengemukakan penyesuaian yang dilakukannya terhadap mahasiswa mengenai penyampaian materi dan tugas. "Penyesuaian pertama yang saya lakukan adalah menanyakan langsung kepada salah satu mahasiswa untuk memberikan contoh dari materi yang sudah saya bahas sebelumnya. Kemudian yang kedua penyesuaian dalam hal memberi tugas, saya menuntut mahasiswa untuk lebih interaktif dan biasanya saya memberikan tugas ke mahasiswa untuk dikerjakan langsung dan dikirimkan melalui kolom chat pada Zoom untuk langsung saya beri nilai, sehingga saya bisa menguji mahasiswa. Akan tetapi jika perkuliahan secara tatap muka atau offline lebih sulit untuk memeriksa pekerjaan mahasiswa secara langsung sedangkan secara online lebih mempermudah saya dalam memeriksa pekerjaan tersebut" (Zakiyah, Wawancara Penelitian, 10 Novermber 2020).

Informan menjelaskan bahwa terdapat beberapa penyesuaian yang sangat berbeda pada perkuliahan tatap muka (Offline) dan perkuliahan jarak jauh (Online). Penyesuaian yang pertama adalah pada sesi diskusi, jika perkuliahan secara tatap muka dosen akan memberikan waktu kepada mahasiswa untuk menanyakan materi yang masih belum dimengerti, tetapi penyesuaian yang dilakukan oleh informan untuk mengantisipasinya adalah informan lebih memilih mahasiswa aktif untuk menjawab pertanyaan yang sudah dibuat dari bahan materi yang sebelumnya sudah di ajarkan kepada mahasiswa. Hal ini sangat efektif agar dosen mengetahui umpan balik 
Website: https://ojs.unikom.ac.id/index.php/common

DOI Jurnal: https://doi.org/10.34010/common

DOI Artikel: https://doi.org/10.34010/common.v4i2.4436

yang diberikan oleh mahasiswa ketika perkuliahan berlangsung. Hal ini juga dijelaskan Informan mengenai umpan balik yang diberikan mahasiswa setelah melaksanakan e-learning menggunakan aplikasi Zoom Cloud Meeting. "Saya bisa mengetahui feedback dari mahasiswa itu dengan cara menanyakan secara langsung kepada setiap mahasiswa dengan menggunakan materi yang baru saya sampaikan agar saya tahu mahasiswa sudah memahami materi yang saya berikan atau belum, karena menurut saya strategi ini lebih efektif dibandingkan dengan menggunakan metode yang biasa saya lakukan di dalam kelas" (Zakiyah, Wawancara Penelitian, 10 Novermber 2020).

Persiapan lain yang diperlu dipersiapkan untuk menunjang proses e-learning menggunakan aplikasi Zoom Cloud Meeting yang dilakukan oleh Koordinator Penjaminan Mutu (QA) Program Studi Ilmu Komunikasi Unikom, "Dalam konteks sebagai koordinator QA, tanggung jawab saya bekerjasama dengan Program studi lebih kepada pengawasan proses belajar mengajarnya, kalau pun persiapan lebih pada Rencana Pembelajaran Semester (RPS) setiap mata kuliah, bagaimana RPS tetap dilaksanakan melalui e-learning" (Purwaningwulan, Wawancara Penelitian, September 2020).

Perencanaan materi tetap mengacu pada perencanaan pembelajaran yang disusun sebagai panduan bagi mahasiswa dalam melaksanakan kegiatan perkuliahan selama satu semester untuk mencapai capaian pembelajaran yang telah ditetapkan. Hanya saja pada masa pandemi kali ini metode penyampaiannya berbeda dari tatap muka menjadi jarak jauh secara daring, dan perbedaan ini perlu penyesuaian dan persiapan dalam penyampaian materi yang akan disampaikan kepada mahasiswa untuk mencapai pemahaman.
RPS dan pembelajaran merupakan dua hal yang berbeda namun erat kaitanya antara satu dengan lainnya. RPS pada dasarnya merupakan suatu perencanaan, menyeluruh, dan mencangkup kegiatan dan pengalaman yang perlu disediakan yang dimana setiap pelajaran identik dengan sistem yang berpedoman pada kurikulum.

Menurut informan Sodiq, biasanya ada beberapa dosen yang akan membagikan daftar materi apa saja yang akan diajarkan, biasanya hal ini dilakukan oleh dosen pada saat pertama kali atau semester pertama dimulai dimana dosen akan memberikan RPS kepada mahasiswa untuk mengetahui materi apa saja yang akan dibahas. Hal ini pun selaras dengan yang dikatakan oleh Informan Erivinna, menjelaskan dosen akan membagikan materi berupa slide presentasi atau makalah untuk dapat dipelajaran oleh mahasiswanya. Ervinna Engwin mengatakan bahwa, "Hampir semua dosen memberikan gambaran terkait materi yang akan dipelajari, meskipun hanya berbentuk RPS" (Sodiq, Wawancara Penelitian, 10 September 2020).

E-learning pasti mempunyai perbedaan yang signifikan dengan perkuliahan secara tatap muka. Ada kelebihan dan kekurangan yang terdapat pada sistem e-learning. Mulai dari penyampaian materi yang diberikan oleh dosen, sesi diskusi yang pasti berbeda, hingga pengumpulan tugas dan absensi yang dilakukan pun pasti berbeda. "Zoom Meeting menurut saya lebih bisa menggantikan perkuliahan tatap muka karena mahasiswa bisa menangkap seluruh pesan komunikasi yang saya sampaikan baik verbal maupun non verbal. yang kedua mahasiswa bisa bertanya kemudian dalam zoom meeting juga saya bisa kasih contoh contoh lebih leluasa kemudian bahkan saya bisa kasih bahan candaan yang akan membuat mahasiswa lebih bergairah dan tidak monoton jadi ada aspek interaksi, aspek transaksi dan juga ada aspek persuasi” 
Website: https://ojs.unikom.ac.id/index.php/common

DOI Jurnal: https://doi.org/10.34010/common

DOI Artikel: https://doi.org/10.34010/common.v4i2.4436

(Zakiyah, Wawancara Penelitian, 10 September 2020).

Pada proses pembelajaran dengan metode e-learning yang diberikan oleh dosen kepada mahasiswa juga mengalami perubahan. Informan mahasiswa pun menjelaskan proses e-learning yang dibutuhkan mahasiswa itu seperti apa. Hal ini diaparkan melalui wawancara oleh informan Ervinna Engwin. "Menurut saya pribadi, banyak keterbatasan selama proses belajar melalui aplikasi Zoom Cloud Meeting ini. Materi dari pembelajaran juga dijelaskan tidak secara mendetail dan mendalam lebih kepada poinnya saja, dikarenakan waktu, koneksi internet, dan keterbatasan kuota dari setiap mahasiswa dan dosen berbeda-beda. Proses pembelajaran yang saya inginakan itu lebih kearah pembelajaran yang simpel dan tidak terlalu kaku. Biasanya perkuliahan online itu lebih terpaku pada slide presentasi" (Engwin, Wawancara Penelitian, 06 September 2020). Menurut penuturan informan selanjutnya, mengenai proses $e$-learning yang dibutuhkan oleh mahasiswa itu adalah ketegasan dari dosen untuk memberikan materi.

Persiapan merupakan suatu kegiatan dalam rangka menyusun langkah-langkah yang akan dilaksanakan untuk mencapai tujuan yang ditentukan. Menyusun perencanaan dapat disusun berdasarkan kebutuhan dalam jangka waktu tertentu sesuai dengan keinginan pembuat perencanaan "Tujuannya karna memang sedang adanya pandemi, jadi pembelajaran harus tetap dilakukan secara e-learning. Sebetulnya pembelajaran yang efektif itu adalah tatap muka tapi karna kondisi seperti ini tidak memungkinkan, salah satu jalannya menggunakan Aplikasi Zoom Cloud Meeting dan ini merupakan salah satu aplikasi yang bagus untuk bisa langsung share pembelajaran ke mahasiswa. Inti tujuannya adalah untuk mengefektifkan pembelajaran perkuliahan walaupun tidak bertemu secara langsung atau tatap muka" (Prayoga, Wawancara Penelitian, 10 September 2020).

Dalam hal ini, perencanaan e-learning yang baik haruslah dapat menarik para peserta yang terlibat dengan menampilkan pembelajaran yang interaktif, sehingga membuat pengguna tetap betah berada dalam kelas virtual tersebut.

\section{Implementasi Aplikasi Zoom Cloud Meeting sebagai Media E-Learning Dalam Mencapai Pemahaman Mahasiswa Di Tengah Pandemi Covid-19}

Implementasi merupakan sebuah tindakan yang dilakukan sesuai rencana yang telah dibuat berdasarkan perencanaan. Adapun implementasi yang dilakukan Program Studi Ilmu Komunikasi di Unikom adalah melakukan Pembelajran e-learning melalu aplikasi Zoom Cloud Meeting dalam mencapai pemahaman mahasiswa di tengah pandemi Covid-19. Dalam mengimplementasikan elearning, dosen dan mahasiswa berdasarkan dari perencanaan yang sebelumnya telah ditetapkan.

Untuk mencapai pemahaman mahasiswa pada e-learning ada sebuah proses yang harus dijalani. Implementasi merupakan penerapan yang dilakukan berdasarkan RPS yang dibuat. Isi materi yang disampaikan oleh dosen sangat lah penting, menggunakan media bantu lainnya seperti slide presentasi, video, atau kuis yang dibuat oleh dosen. Setelah itu dalam penyampaian materi pun harus dapat dilaksanakan sesederhana mungkin dengan segala keterbatasan yang ada. Karena pada proses e-learning ini menggunakan internet pasti akan banyak kendala yang terjadi seperti koneksi internet dan keterbatasan jaringan internet. Maka dosen harus dapat menyampaikan materi secara efektif dengan waktu yang tersedia baik cara menjelaskanya, membagi waktu penjelasan hingga diskusi. 
Website: https://ojs.unikom.ac.id/index.php/common

DOI Jurnal: https://doi.org/10.34010/common

DOI Artikel: https://doi.org/10.34010/common.v4i2.4436

Karakter dan suasana belajar yang menyenangkan perlu dibangun oleh dosen pada saat berlangsungnya e-learning bertujuan agar dapat menarik perhatian mahasiswa pada saat perkuliahan.

Implementasi ketika memberikan materi pembelajaran agar dapat dipahami oleh setiap mahasiswa dengan menggunakan Aplikasi Zoom Cloud Meeting dosen melakukan teknik presenting, dimana pada teknik ini biasa dilakukan juga pada saat dosen mengajar secara langsung atau tatap muka. Aplikasi Zoom Cloud Meeting ini memiliki fitur untuk menunjang slide presentasi tersebut dengan cara klik Share Screen. Tampilan slide presentasi yang ditampilan pun cukup jernih sehingga mahasiswa dapat membaca materi dengan jelas. Selain itu, pada proses e-learning untuk mempersentasikan tugas yang telah dikerjakan oleh mahasiswa pun masih tetap bisa dilakukan dan para partisipan yang ada didalamnya dapat menampilkan slide presentasi secara bergiliran.

Dalam implementasi ini dosen dapat menjelaskan atau memaparkan materinya tidak hanya dengan slide presentasi tetapi menampilkan video, tulisan, atau gambar, seperti yang biasa dilakukan di dalam kelas tatap muka secara langsung, begitu pula dengan mahasiswa tetap dapat langsung mempelajari dan mempresentasikan hasil tugas yang telah dikerjakan. Aplikasi Zoom Cloud Meeting ini tentu memudahkan dosen dan mahasiswa dalam melaksanakan perkuliahan di tengah pandemi Covid-19. Menurut Informan, dalam mencapai pemahaman melalui e-learning ini harus ada kerja sama antara dosen dan mahasiswa. Karena dalam metode e-learning lebih menekankan pada ketelitian dan kejelian mahasiswa dalam menerima dan mengolah informasi yang disajikan oleh dosen. "Untuk mencapai pemahaman harus ada kerjasama yang baik antara dosen dengan mahasiswa, di satu sisi dosen memang harus menyiapkan materi yang lebih ringkas dan jelas karena keterbatasan interaksi dengan mahasiswa, di sisi lain dari mahasiswanya juga ada niat baik dan keseriusan untuk memperhatikan dan memahami meskipun tidak diawasi secara face to face" (Purwaningwulan, Wawancara Penelitian, September 2020)

Terminologi e-learning sendiri dapat mengacu pada semua kegiatan pelatihan yang menggunakan media elektronik atau teknologi informasi (Effendi dan Zhuang, dalam Susanti 2008:52). Materi atau gambaran pembelajaran yang akan dibahas biasanya diberikan berupa RPS yang dikirim secara daring untuk dipelajari terlebih dahulu oleh mahasiswa. "Kalau materi nya udah dikirim sebelum perkuliahan dimulai, saya persiapan baca dan memahami materi dulu. Dan setelah perkuliahan selesai materi yang tadi saya baca baca lagi ditambah dari catatan yang saya buat selama dosennya menjelaskan materi" (Febrianti, Wawancara Penelitian, 07 September 2020). Informan menjelaskan bahwa cara belajar yang dilakukan adalah dengan membaca materi sebelum perkuliahan dimulai dan setelah perkuliahannya selesai, melakukan review terhadap materi yang sudah dibahas sebelumnya.

Cara belajar mahasiswa dalam elearning dituntut untuk lebih mandiri dan lebih aktif dalam memahami materi dengan membaca dan mengulas kembali materi pada setiap mata kuliah yang telah disampaikan, sehingga jika ada materi yang belum dapat dipahami dapat dibuat pertanyaannya dan ditanyakan pada pertemuan e-learning selanjutnya atau mencari tahu sendiri melalui sumber lain seperti buku maupun pada situs internet yang tersedia. Seperti yang dilakukan oleh salah satu informan,"Kembali mempelajari apa yang telah disampaikan dosen di luar waktu perkuliahan, karena perkuliahan daring tidak akan maksimal, jadi saya rasa masing-masing mahasiswa harus 
Website: https://ojs.unikom.ac.id/index.php/common

DOI Jurnal: https://doi.org/10.34010/common

DOI Artikel: https://doi.org/10.34010/common.v4i2.4436

mencari materi secara mandiri" (Sodiq, Wawancara Penelitian, 10 September 2020).

Target yang mahasiswa inginkan pada proses e-learning dengan menggunakan Aplikasi Zoom Cloud Meeting ini tentunya adalah pencapaian pemahaman dan tetap mendapatkan materi yang sesuai, "Target yang ingin saya capai dalam e-learning adalah semua informasi, ilmu, dan sensasi belajar bisa didapatkan meski secara daring" (Febrianti, Wawancara Penelitian, 07 September 2020).

Selain itu menurut infroman mahasiswa dalam melaksanakan e-learning pada masa SFH (Study From Home) seperti saat ini tantangan terbesarnya adalah rasa malas untuk serius mendengarkan dosen menjelaskan materi. Tempat seperti di rumah atau dalam kamar menjadi alasan mahasiswa sulit untuk mengikuti pembelajaran secara serius seperti situasi formal dalam kelas. Akan tetapi jika mahasiswa mempunyai target untuk mencapai pemahaman pada materi perkuliahan dengan baik, mahasiswa tersebut akan mencari cara untuk melawan rasa malas tersebut dengan mempunyai niat dan tekad yang lebih besar untuk serius dalam mengikuti perkuliahan secara daring.

Selain mempunyai target dan mencari cara agar dapat mencapai target mahasiswa dalam melaksanakan perkuliahan secara $e$ learning, metode yang dilakukan oleh dosen pada saat melaksanakan perkuliahan pun ikut mempengaruhi mahasiswa dalam mencapai target mereka. Dosen mempunya cara atau metodenya sendiri-sendiri dalam melakukan pembelajaran online atau offline maka pasti akan berbeda-beda dengan keinginan mahasiswa itu sendiri. "Karakteristik yang saya bangun dalam proses pembelajaran perkuliahan secara online maupun offline agar mahasiswa dapat memahami materi yang saya sampaikan biasanya saya selingi dengan bercandaan agar mahasiswa tidak bosan jika saya harus terus memberi materi kepada mahasiswa" (Zakiyah, Wawancara Penelitian, 10 September 2020).

Mahasiswa dituntut untuk lebih aktif selama proses e-learning berlangsung untuk menyimak, bertanya, dan mengikuti alur diskusi yang telah dosen sediakan. Selain itu untuk menumbuhkan pemahaman mahasiswa dalam melaksanakan perkulihan secara $e$ learning, penambahan variasi dalam pembelajaran akan sangat membantu. "Biasanya ada tugas sederhana namun mengena tentang materi pembelajaran, kemudian secara acak dosen meminta mahasiswa mempresentasikan sebentar tugasnya tersebut. Pernah juga untuk mata kuliah Periklanan saya memberikan contohcontoh iklan, namun karena faktor koneksi malah contoh iklan tidak tersampaikan dengan baik" (Purwaningwulan, Wawancara Penelitian, September 2020).

Untuk mengetahui tingkat pemahaman mahasiswa dalam melaksanakan perkuliahan secara e-learning pasti akan menghasilkan hasil yang berbeda-beda. Hal ini pun yang ditemukan peneliti pada saat sesi wawancara dengan para informan mahasiswa yang berbeda-beda tingkatan di Program studi Ilmu Komunikasi Unikom. Seperti yang dilakukan oleh Informan Nazla, cara mengetahui tingkat pemahaman dalam melaksanakan e-learning dengan menggunakan aplikasi Zoom Cloud Meeting. "Cara saya mengetahui tingkat pemahaman saya dalam melaksanakan perkuliahan ini dengan cara menjawab dari pertanyaan-pertanyaan dosen yang telah disediakan di jam trakhir kuliah (sesi diskusi) atau pada saat uji kemampuan seperti UTS (Ujian Tengah Semester) dan UAS (Ujian Akhir Semester) dilaksanakan. Jika saya dapat menjawab semua pertanyaan yang diberikan maka saya mengetahui saya dapat memahami materi atau pembelajaran yang diberikan oleh dosen pada saat perkuliahan" (Febrianti, Wawancara Penelitian, 07 September 2020). 
Jurnal Common | Volume 4 Nomor 2 | Desember 2020

Website: https://ojs.unikom.ac.id/index.php/common

DOI Jurnal: https://doi.org/10.34010/common

DOI Artikel: https://doi.org/10.34010/common.v4i2.4436

Menurut Bandalaria (2003:32-41) menyatakan bahwa, ada tiga masalah utama yang menghambat dalam menentukan efektifitas penerapan Virtual learning, yang pertama dispositional Problems, yaitu masalah yang mengacu pada pribadi masing masing, seperti sikap rasa percaya diri dan gaya belajar. Kedua Circumstantial problems, yaitu masalah yang berkaitan dengan kondisi khusus seperti lokasi geografis, ketersedian waktu, dan sebagainya. Ketiga, tecnical Problem, yaitu masalah yang berkaitan dengan munculnya hardware dan program software yang digunakan dalam belajar online. Seperti yang disampaikan oleh informan dosen terkait keseriusan dari masing-masing individu mahasiswa dalam menyikapi e-learning. "Koneksi, keterbatasan waktu dan saya liat niat dan keseriusan dari mahasiswanya (Tidak semua mahasiswa niat dan serius karena tidak diawasi secara langsung)" (Purwaningwulan, Wawancara Penelitian, September 2020).

Hambatan yang terjadi pada saat $e$ learning itu lebih banyak dibandingan perkuliahan secara tatap muka langsung. Hal ini pun pasti mempengaruhi tingkat pemahaman mahasiswa karena dengan adanya hambatan ini akan menjadi noise pada saat perkuliahan dimulai. Hambatan yang terjadi pun berbeda dengan hambatan pada perkuliahan secara tatap muka langsung. "Kekurangan yang pertama ya durasi, kalau yang gratis. Karena kita juga tidak difasilitasi oleh pihak kampus untuk menggunakan zoom cloud meeting yang berbayar, jadi yang paling terasa kekurangannya ya durasi biasanya lagi enak menjelaskan tiba tiba berhenti" (Prayoga, Wawancara Penelitian, 10 September 2020)

Maka untuk memaksimalkan penggunaan aplikasi tersebut diusahakan pendidik memiliki fasilitas aplikasi Zoom Cloud Meeting Premium atau berbayar. Informan yang memiliki aplikasi Zoom Cloud Meeting Premium mengatakan bahwa tidak ada hambatan pada Aplikasi Zoom Cloud
Meeting karena sudah berlangganan, hambatan yang mungkin dapat terjadi kemungkinan pada sinyal saja. Seperti penjelasan informan berikut, "Kalau menurut saya, karena saya menggunakan Zoom Cloud Premium menurut saya tidak ada kekurangan karena saya bisa menggunakan semua fitur yang ada di zoom cloud meeting" (Zakiyah, Wawancara Penelitian, 10 September 2020).

Selain itu pemaham terhadap materi yang diterima mahasiswa tidak hanya pada saat itu saja, tetapi berupa penerapan secara langsung dalam kehidupannya seperti yang disampaikan informan berikut ini, "Saya juga biasanya memberikan tugas secara langsung setelah saya menyampaikan materi kuliah di hari itu agar saya bisa mengetahui sejauh mana mahasiswa dapat memahami materi yang saya berikan karena saya tidak mau mahasiswa hanya mengetahui tataran kognisi saja yang penting mahasiswa dapat mengaplikasikan di kehidupan nyata dari materi yang saya sampaikan" (Zakiyah, Wawancara Penelitian, 10 September 2020).

\section{Evaluasi Aplikasi Zoom Cloud Meeting sebagai Media E-Learning Dalam Mencapai Pemahaman Mahasiswa di Tengah Pandemi Covid-19}

Setelah melaksanakan perkuliahan dengan metode e-learning menggunakan Aplikasi Zoom Cloud Meeting, perlu sebuah perbaikan dengan tujuan agar Pendidikan Tinggi berserta dosen dan mahasiswa dapat mengembangkan metode e-learning terutama dalam menggunakan Aplikasi Zoom Cloud Meeting.

Evaluasi menurut Kumano (2001) merupakan penilaian terhadap data yang dikumpulkan melalui kegiatan asesmen. Dalam proses e-learning tentu membutuhkan evaluasi untuk mengetahui pemahaman mahasiswa pada kegiatan belajar mengajar. 
Website: https://ojs.unikom.ac.id/index.php/common

DOI Jurnal: https://doi.org/10.34010/common

DOI Artikel: https://doi.org/10.34010/common.v4i2.4436

Selain itu, untuk mengetahui seberapa efektifnya menggunakan aplikasi Zoom Cloud Meeting dalam melaksanakan e-learning. Dalam mengembangkan suatu materi juga perlu adanya evaluasi yang berkelanjutan berdasarkan apa yang sudah diimplementasi, dalam hal ini dosen dan program studi harus mengevaluasi apa saja yang harus dikembangkan dalam sistem e-learning ini. Selanjutnya, mahasiswa pun harus mengevaluasi hasil yang dikerjakan selama sistem e-learning, mengnai kekurangan dan mengevaluasi pemahaman mereka selama sistem e-learning ini berlangsung yang berpengaruh terhadap nilai yang didapat.

Evaluasi yang dilakukan oleh Program Studi pada e-learning menggunkan Aplikasi Zoom Cloud Meeting dalam meningkatkan proses belajar ditengah pandemi, dijelaskan oleh informan sebagai berikut: "Dilakukan di rapat program studi, namun sejauh ini tidak ada masalah yang berarti. Setiap ada kendala, misalnya ada dosen yang belum familiar dengan teknologi pembelajaran, langsung oleh program studi diberikan bimbingan dalam pelaksanaan pembelajaran" (Purwaningwulan, Wawancara Penelitian, September 2020).

Evaluasi juga perlu dilakukan oleh dosen yang bersangkutan seperti yang dilakukan oleh salah satu informan, "Sejauh ini saya bisa menilai perkuliahan ini dapat berjalan secara efektif ya salah satunya ketika saya memberikan tugas lalu mereka (mahasiswa) dapat mengerjakan tugasnya dengan baik sesuai dengan materi kemudian dengan hasil dari UTS dan UAS juga $70-80 \%$ sesuai dengan yang diharapkan, ya istilahnya saya dapat berasumsi mereka mengerti tentang materi yang saya sampaikan" (Prayoga, Wawancara Penelitian, 10 September 2020).

Faktor Sumber Daya Manusia sebagai pemeran dalam e-learning ini tidak hanya berkaitan dengan pendidik (guru maupun dosen), tetapi juga tenaga kependidikan lainnya, khususnya tim teknis pendukung implementasi e-learning baik pada tingkat fakultas maupun program studi. Dari sisi dosen adalah berkaitan dengan kompetensi dan kemauan mereka untuk mengembangkan $e$ learning. Evaluasi lain adalah adanya keinginan pemberian fasilitas untuk menggunakan aplikasi Zoom Cloud Meeting Premium dari pihak Perguruan Tinggi agar dapat memaksimalkan proses e-learning. Hal ini sulit terealisasi, terutama ketika Perguruan Tinggi sudah memiliki fasilitas video conference tersendiri. Seperti Unikom, yang sudah memiliki fasilitas BigBlueButtonBN pada LMS Unikom, tidak dibatasi waktu dan memiliki fitur yang tidak kalah jika dibandingkan dengan Zoom Cloud Meeting. Hanya saja, masih banyak sivitas akademika yang belum menguasai penggunaan BigBlueButtonBN pada LMS Unikom. Selain itu, fasilitas ini juga membutuhkan jaringan dan koneksi internet yang tinggi.

Untuk melakukan penelitian yang berfokus pada penggunaan Aplikasi Zoom Cloud Meeting sebagai media e-learning merupakan bagian dari unsur komunikasi, salah satunya adalah pesan atau informasi yang disampaikan oleh dosen dan menggunakan media dalam penyampaian pesannya dan mendapatkan umpan balik langsung dari komunikannya. Bila komunikasi yang terjadi antara pihak yang terlibat dapat terjalin dengan baik maka akan menghasilkan umpan balik yang baik juga atau selaras dengan tujuan dari terjalinnya komunikasi tersebut.

Menilik dari fungsi komunikasi yang dikemukakan oleh Effendy (2008) dalam buku dimensi-dimensi komunikasi yaitu sebagai, public information, public education, public persuasion, public entertaiment. Menurut observasi, dalam fungsi komunikasi terdapat informasi yang disampaikan oleh narasumber, pada penelitian ini informasi yang disampaikan adalah berupa materi perkuliahan, yang dapat diakses oleh mahasiswa. Adapun Aplikasi Zoom Cloud 
Website: https://ojs.unikom.ac.id/index.php/common

DOI Jurnal: https://doi.org/10.34010/common

DOI Artikel: https://doi.org/10.34010/common.v4i2.4436

Meeting merupakan media untuk menyampaikan sebuah informasi dan pertukaran informasi. Fungsi edukasi, dengan menggunakan aplikasi Zoom Cloud Meeting, dosen dan mahasiswa dapat melaksanakan perkuliahan layaknya perkuliahan tatap muka dalam kelas dibantu dengan teknologi. Dengan situasi pandemi seperti saat ini tidak memungkinkan untuk adanya perkuliahan tatap muka secara langsung, maka menggunakan aplikasi Zoom Cloud Meeting sebagai salah satu alternatif pelaksanaan sistem e-learning. Dosen dan mahasiswa tetap dapat melakukan sesi diskusi, melakukan presentasi, pengumpulan tugas, hingga menggunakan aplikasi Zoom Cloud Meeting ini untuk melakukan Webinar (Web Seminar) hingga acara lainnya.

Evaluasi yang dilakukan dapat mendorong dosen untuk lebih giat melakukan perbaikan pembelajaran yang telah dilakukan secara terus menerus sehingga dapat meningkatkan kualitas tenaga pendidik yang lebih memupuni sesuai dengan mengikuti perkembangan zaman. Dalam pembelajaran dibutuhkan tenaga pendidik yang tidak hanya mampu mengajar dengan baik tetapi juga dengan peka mampu melakukan evaluasi dengan baik untuk menyesuaikan kondisi terkini. Kegiatan evaluasi sebagai bagian dari program pembelajaran perlu lebih dioptimalkan. Evaluasi tidak hanya bertumpu pada penilaian hasil belajar, tertapi juga perlu penilaian terhadap kualitas dari proses pembelajaran itu sendiri.

\section{Kesimpulan dan Rekomendasi}

\subsection{Kesimpulan}

Kesimpulan penelitian, perencanaan dari pemanfaatan aplikasi Zoom Cloud Meeting sebagai media e-learning terdiri dari persiapan yang dilakukan oleh dosen maupun mahasiswa pada setiap mata kuliah. Aplikasi Zoom Cloud
Meeting dipilih sebagai media pembelajaran di tengah pandemi Covid-19 karena aplikasi tersebut memiliki fitur yang lengkap yang dapat menunjang proses e-learning serta penggunaannya yang mudah untuk digunakan. Persiapan yang dilakukan dosen sama dengan pembelajaran secara tatap muka hanya saja suasana dan pelaksanaan pembelajaran yang lebih fleksibel agar mahasiswa tidak cepat bosan. Sedangkan persiapan yang dilakukan oleh mahasiswa lebih bersifat teknis seperti menyiapkan perangkat baik laptop maupun gadget dan jaringan internet.

Implementasi e-learning dengan menggunakan aplikasi Zoom Cloud Meeting dilakukan sesuai dengan perencanaan yang sudah dibuat sebelumnya. Dosen menyampaikan materi pembelajaran dengan teknik presenting atau menjelaskan secara langsung tanpa ada slide presentasi. Aplikasi Zoom Cloud Meeting memiliki fitur share screen yang dapat digunakna untuk memperlihatkan materi atau slide presentasi baik oleh dosen maupun mahasiswa.

Evaluasi dilakukan untuk mengetahui hasil sistem pembelajaran, baik yang menyangkut tentang tujuan, materi, metode, media, maupun penilaian itu sendiri. Pada $e$ learning dengan menggunakan aplikasi Zoom Cloud Meeting, evaluasi memberikan informasi mengenai kendala yang terjadi saat proses e-learning berlangsung melalui aplikasi Zoom Cloud Meeting seperti masalah koneksi internet yang menjadi hambatan komunikasi. Lalu sulitnya menyelenggarakan proses pembelajaran yang bersifat dua arah karena mahasiswa yang cenderung pasif sehingga proses e-learning menjadi membosankan. Dosen juga tidak bisa melihat komunikasi nonverbal mahasiswa secara langsung sebagai umpan balik dari mahasiswa sehingga sulit untuk mengetahui pemahaman mahasiswa. Aplikasi Zoom Cloud Meeting memberikan beberapa pilihan, tetapi sebagian besar proses pembelajaran dilakukan dengan menggunakan 
Website: https://ojs.unikom.ac.id/index.php/common

DOI Jurnal: https://doi.org/10.34010/common

DOI Artikel: https://doi.org/10.34010/common.v4i2.4436

akun gratis sehingga terdapat pembatasan waktu (40 menit). Untuk dapat menggunakan Zoom Cloud Meeting tanpa dibatasi waktu, pengguna harus melakukan upgrade menjadi akun Premium atau berbayar dengan biaya yang cukup membebani mengingat situasi pandemi. Perguruan Tinggi yang sudah memiliki fasilitas video conference tersendiri, seperti Unikom, tidak akan memfasilitasi sivitas akademika-nya dengan akun premium, karena BigBlueButtonBN pada LMS Unikom, tidak dibatasi waktu dan memiliki fitur yang tidak kalah jika dibandingkan dengan Zoom Cloud Meeting. Hanya saja, selain kurangnya penguasaan dari sivitas akademika, BigBlueButtonBN pada LMS Unikom juga membutuhkan jaringan dan koneksi internet yang tinggi.

Pemanfaatan aplikasi Zoom Cloud Meeting sebagai media e-learning secara umum dapat membantu dalam mencapai pemahaman mahasiswa di tengah pandemi melalui berbagai fitur yang mendukung pelaksanaan e-learning, hal ini terjadi setelah semua pihak yang terlibat dapat beradaptasi dengan sistem e-learning. Tetapi, perlu dilakukan penelitian lanjutan mengenai dampak e-learning dalam meningkatkan kualitas belajar mahasiswa. Karena pemahaman mahasiswa belum tentu berbanding lurus dengan kualitas belajar.

\subsection{Rekomendasi}

Rekomendasi yang dapat diberikan melalui penelitian ini adalah:

1. Faktor pendidik juga memiliki peranyang sangat besar dalam proses $e$ learning terutama kemampuan dalam menggunakan perangkat teknologi. Sehingga diharapkan pendidik, baik guru maupun dosen senantiasa terus meningkatkan kemampuan dan penguasaan teknologi, agar mampu menghadapi dan memberikan solusi terhadap kendala yang terjadi dalam pembelajaran dengan sistem e-learning.

2. Pendidik baik guru maupun dosen dalam menjalankan sistem e-learning agar memiliki toleransi yang lebih tinggi terhadap permasalahan dan hambatan yang dihadapi oleh peserta didik, baik siswa maupun mahasiswa. Karena situasi yang dihadapi serta fasilitas yang dimiliki peserta didik berbeda-beda.

3. Peserta didik baik siswa maupun mahasiswa juga dituntut untuk mengikuti sistem e-learning ini dengan tidak melupakan nilai dan norma yang berlaku. Bahwa e-learning hanyalah metode pengganti pembelajaran tatap muka, tetapi pada dasarnya tata cara yang diselenggarakan tetaplah sama. Sehingga tetap dibutuhkan rasa hormat dan saling menghargai dalam proses $e$ learning, pada saat proses pembelajaran berlangsung maupun ujian.

\section{Daftar Pustaka}

\section{Buku}

Allen, Michael. 2013. Michael Allen's Guide to E-learning. Canada: John Wiley \& Sons.

Arikunto, Suharsimi. (2009). Dasar-dasar Evaluasi Pendidikan. Jakarta: Bumi Aksara.

Effendy, Onong Uchjana. 2008. Dinamika Komunikasi. Bandung: Remaja. Rosdakarya.

Kumano, Y. 2001. Authentic Assessment and Portfolio Assessment: It's Theory and Practice. Jepang: Shizouka University. 
Website: https://ojs.unikom.ac.id/index.php/common DOI Jurnal: https://doi.org/10.34010/common

DOI Artikel: https://doi.org/10.34010/common.v4i2.4436

Moleong, Lexy J. 2014. Metode Penelitian Kualitatif, Edisi Revisi. Bandung: Remaja Rosdakarya.

Pranoto, Alvini, dkk. 2009. Sains dan Teknologi. Jakarta: PT Gramedia Pustaka Utama.

Saud, Udin, Syaefudin. 2010. Inovasi Pendidikan. Bandung: Alfabeta.

\section{Jurnal}

Meliyani, Supriyanto, Muhammad Rahmattullah. 2019. Pengaruh Pemanfaatan Simari Sebagai Implementasi Pembelajaran Berbasis ELearning Terhadap Hasil Belajar Mahasiswa Program studi Pendidikan Ekonomi. Banjarmasin: Jurnal Pendidikan dan Ilmu Sosial Volume 29, Nomor 1 Juni 2019. Diperoleh dari: http://journals.ums.ac.id/index.php/jpis/ article/view/8232/4573 (Desember 2020 pukul 19:30)

\section{Skripsi}

Renaldi, Aldi Salman. 2020. Penggunaan Youtube Channel Oleh Trainer Dj Arie School Bandung. Bandung: Skripsi, Program Studi Ilmu Komunikasi, Fakultas Ilmu Sosial dan Ilmu Politik, Universitas Komputer Indonesia.

\section{Artikel Website}

BBC News Media Indonesia. 2020. Virus corona: Seberapa aman aplikasi Zoom yang marak dipakai WFH, tapi kini dilarang Taiwan?. Diperoleh dari https://www.bbc.com/indonesia/majalah -52215642 (Tanggal akses 23 September 2020, pukul 20:14) 